\title{
Reversal of Hartmann's procedure is still a high-morbid surgery?
}

\author{
Ozan Akıncı, M.D., ${ }^{1} \odot$ Müge Yurdacan, M.D., ${ }^{2}$ Başar Can Turgut, M.D., ${ }^{2}$ \\ Server Sezgin Uludağ, M.D., ${ }^{2}$ ○ Osman Şimşek, M.D. ${ }^{2}$
}

${ }^{1}$ Department of General Surgery, Hakkari State Hospital, Hakkari-Turkey

${ }^{2}$ Department of General Surgery, İstanbul University-Cerrahpaşa, Cerrahpaşa Faculty of Medicine, İstanbul-Turkey

\begin{abstract}
BACKGROUND: This study evaluated the outcome of the reversal of Hartmann's procedure based on preoperative and intraoperative risk factors.
\end{abstract}

METHODS: We retrospectively reviewed 78 cases, whom we applied the Hartmann's procedure either electively or under emergency conditions in our clinic between the years 2010 and 2016.

RESULTS: Of the cases reviewed in this study, 45 patients were males, and 33 patients were females. Of all cases included in this study, 32 cases were operated due to malignancies, 15 cases were operated due to a perforated diverticulum, and II cases were operated due to sigmoid volvulus. Reversal of Hartmann's was performed in 32 cases. The morbidity and mortality rates for the reversal of Hartmann's procedure were $37.5 \%$ and $0.0 \%$, respectively.

CONCLUSION: The reversal of Hartmann's procedure appears to be a safe operation with acceptable morbidity rates. If the correct patient selection, correct operation timing and meticulous surgical preparation are performed, the risk of morbidity and mortality of the reversal of Hartmann's procedure can be minimized.

Keywords: Hartmann's procedure; morbidity; mortality; the reversal of Hartmann.

\section{INTRODUCTION}

The Hartmann's procedure was first described in 1923 by French surgeon Henry Hartmann as an alternative technique to abdominoperineal resections in left colon cancers and in high-risk cases. ${ }^{[1]}$ Being developed to reduce the mortality associated with anastomotic leakages, this technique can be applied in a wide variety of indications today, including perforated diverticulitis, ischemic colitis, colonic obstructions, traumatic perforations, volvulus, inflammatory colitis, and anastomotic leakages. ${ }^{[2]}$ The use of new and broad-spectrum antibiotics over time and the preoperative colon cleansing have resulted in the completion of operations with primary anastomosis. ${ }^{[3]}$ Although the use of single-stage procedures for surgical cases with complications, such as diverticulitis and malignancy is more prevalent today, the Hartmann's procedure is still important because of the technical difficulties of single-stage methods, severe peritonitis, and hemodynamic instability.

Reversal of Hartmann's procedure requires a major abdominal surgical approach with a morbidity risk of $16-54 \% .{ }^{[4-7]}$ In addition, $28 \%-81 \%$ of the cases continue to live with a permanent stoma due to the failure of the second-stage operation or due to not being allowed to undergo a second stage operation at all. ${ }^{[4,8-10]}$

In this study, we aimed to investigate the following parameters, including the operative indications, intraoperative and postoperative complications, the duration of the operations, the risks of morbidity and mortality due to $1^{\text {st }}$ and $2^{\text {nd }}$-stage

Cite this article as: Akıncı O, Yurdacan M, Turgut BC, Uludağ SS, Şimşek O. Reversal of Hartmann’s procedure is still a high-morbid surgery?. Ulus Travma Acil Cerrahi Derg 2020;26:255-259.

Address for correspondence: Ozan Akıncı, M.D.

Hakkari Devlet Hastanesi, Genel Cerrahi Kliniği, Hakkari, Turkey

Tel: +90 438 - 2116057 E-mail: ozanakincil987@hotmail.com

Ulus Travma Acil Cerrahi Derg 2020;26(2):255-259 DOI: 10.14744/tjtes.2019.7I725 Submitted: 05.04.2019 Accepted: 21.05.2019 Online: 24.02.2020

Copyright 2020 Turkish Association of Trauma and Emergency Surgery 
operations, as well as evaluating the outcomes of our surgical practices in the individuals who underwent the Hartmann's procedure between the years 2010-2016 in our clinic.

\section{MATERIALS AND METHODS}

Seventy-eight patients who underwent Hartmann's procedure in our clinic between January 2010 and January 2016 were studied retrospectively. Patient information was obtained using the hospital discharge reports, surgery reports and pathology reports. We did not apply for an ethics committee because the study was retrospective.

Resection of the sigmoid colon or rectum, closure of the distal segment, and end colostomy of the proximal segment were referred as the "Hartmann's procedure" and "first-stage operation"; whereas the "reversal of Hartmann's procedure" and "second-stage operation" terms were used to refer to the closure of an ostomy.

The cases were evaluated concerning age, gender, comorbidities, operative indications, intraoperative and postoperative complications, the interval between the Hartmann and the reversal of Hartmann's procedures, duration of the hospital stay, postoperative morbidity and mortality rates (mortality due to any reason within the first 30 days after surgery), and the anastomosis techniques of the reversal of Hartmann's procedure.

\section{RESULTS}

Hartmann's procedure was performed due to various indications in a total of 78 patients during six years. Of all cases, 33 cases were females and 45 were males. The mean age was $63(25-86)$ and 50 (64\%) cases were over 60 years old. Comorbid diseases were present in 56 of the patients. The three most common comorbidities were hypertension (38\%), diabetes mellitus (23\%), and ischemic heart disease (I7\%). According to the American Society of Anesthesiologists (ASA) classification, the majority of cases were in the ASA 2 or ASA 3 category (Table I).

Hartmann's procedure was most common $(n=32,41 \%)$ in the patients with tumors of the rectosigmoid region. Of these, 21 (27\%) were operated due to tumor-associated obstruction and II (14\%) were operated due to a tumor-induced perforation. Other indications requiring the Hartmann's procedure are shown in Table 2.

The mean duration of the first stage operation was 155 minutes and the mean duration of the second stage operation was 185 minutes. The average duration of hospital stay after the first stage operation was 17 days and it was 12 days after the second stage operation.

Intraoperative complications developed in nine (11.5\%) cases during the first stage operation (Table 3). In 32 cases (4I\%),
Table I. Demographic characteristics of the patients $(n=78)$

\begin{tabular}{lcc}
\hline Demographic characteristics & $\mathbf{n}$ & $\%$ \\
\hline Sex & & \\
$\quad$ Male & 45 & 58 \\
$\quad$ Female & 33 & 42 \\
Age (years) & & \\
$\quad<30$ & 3 & 3.8 \\
3 I-40 & 0 & 0 \\
$41-50$ & 9 & 11.5 \\
5 I-60 & 20 & 25.6 \\
$6 I-70$ & 20 & 25.6 \\
$7 \mid-80$ & 18 & 23 \\
$>80$ & 8 & 10.2 \\
American Society of Anesthesiologists & & \\
I & 9 & 11.5 \\
2 & 42 & 53.8 \\
3 & 27 & 34.6 \\
\hline
\end{tabular}

Table 2. The primary indications requiring the Hartmann procedure $(n=78)$

\begin{tabular}{lcc}
\hline Indications & $\mathbf{n}$ & $\%$ \\
\hline Rectosigmoid cancer & 32 & 41 \\
Diverticulum perforation & 15 & 19.2 \\
Sigmoid volvulus & $\mathrm{II}$ & 14.1 \\
Anastomotic leakage & 5 & 6.4 \\
latrogenic trauma & 5 & 6.4 \\
Ischemic colitis & 3 & 3.8 \\
Colovesical fistula & 3 & 3.8 \\
Stricture & 2 & 2.5 \\
Gunshot wound & $\mathrm{I}$ & 1.2 \\
Rectovaginal fistula & $\mathrm{I}$ & 1.2 \\
\hline
\end{tabular}

various surgical and medical postoperative complications were observed (Table 3). The most common of these complications was intraabdominal abscess formation or collections $(n=17)$. Other postoperative complications associated with the first stage operation are shown in Table 3. There was more than one complication in some of the cases. Mortality occurred in II patients (14\%) associated with the first-stage operation.

The interval between the first-stage operation and the reversal of Hartmann was I85 days on the average. Of the $67(86 \%)$ patients who survived the Hartmann's procedure, 32 (4l\%) patients underwent a restorative colorectal anastomosis. The reversal of Hartmann's procedure could not be performed in 35 cases. Of these cases, the second-stage operation could 
Table 3. Intraoperative and postoperative complications associated with the first stage operation

\begin{tabular}{lcc}
\hline Complication type & $\mathbf{n}$ & $\%$ \\
\hline Intraoperative ( $\mathrm{n}=9)$ & & \\
$\quad$ Intestinal injury & 4 & 5.1 \\
Splenic injury & 3 & 3.8 \\
Colonic injury & $\mathrm{I}$ & 1.2 \\
Hemorrhage & $\mathrm{I}$ & 1.2 \\
Postoperative ( $\mathrm{n}=32)$ & & \\
Intraabdominal abscess & 17 & 21.7 \\
Pulmonary infection & 5 & 6.5 \\
Wound infection & 4 & 5.1 \\
Ileus & 4 & 5.1 \\
Urinary tract infection & 4 & 5.1 \\
Pulmonary embolism & 2 & 2.5 \\
Organ evisceration & $\mathrm{I}$ & 1.2 \\
Stomal necrosis & $\mathrm{I}$ & 1.2 \\
\hline
\end{tabular}

not be performed because 16 patients had comorbidities and they were at higher categories of ASA, eight patients withdrew their consents to undergo the second stage of operation, seven patients developed a recurrence of malignancy, and four patients were lost to follow-up surgery. The 30-day postoperative morbidity was $37.5 \%$ and the incidence of 30 day mortality was $0.0 \%$.

In the second-stage operation, stapled or manual anastomoses were created in 26 and six patients, respectively. After the second stage operation, postoperative complications were observed in a total of 12 cases, including wound infections in five cases, strictures of the anastomoses in three cases, anastomosis leakages in two cases, and intraabdominal abscesses in two cases. Three patients with anastomotic strictures were successfully treated with colonoscopic balloon dilatation. In five cases developing anastomotic strictures and anastomotic leakages, it was observed that those anastomoses were created using a stapler.

\section{DISCUSSION}

Although primary anastomotic resection procedures have become popular to treat the pathological lesions of the left colon in recent years, many surgeons prefer multi-stage procedures in cases with diffuse peritonitis, sepsis, and severe obstructions. Resolution of sepsis and developing a surgical strategy for damage control in the first operation is more important for survival compared to the maintenance of intestinal integrity. The restoration of gastrointestinal integrity depends on many factors, including the willingness of the patient, local factors, patient's condition, estimated duration of survival, and the experience of the surgeon.
When the indications of the Hartmann's procedure are examined, non-neoplastic etiologies are common in western societies. However, neoplastic etiologies predominate in Asian communities. ${ }^{[4]}$ In the literature, it has been reported that the rates of the reversal of Hartmann's procedure range from four to $85 \%$, consisting mainly of benign pathologies. [6,11-15] We should note that $86 \%$ of our cases survived after undergoing the Hartmann's procedure, but only $47 \%$ of them were able to undergo a restorative colorectal anastomosis. As mentioned above, the reasons for this include the unsuitability of the patient condition to undergo a second stage operation, the recurrence of malignancies, and the withdrawal of consent by the patients to undergo the operation.

In our study, the patients who underwent the reversal of Hartmann's procedure had been operated because of a perforation of a diverticulum in $40 \%$ of the cases $(n=13)$ and due to malignancies in $37.5 \%$ of the cases $(n=12)$. Of the 32 patients operated with indications associated with malignancies, only 12 cases were able to undergo the second-stage operation. Because the patients with malignant lesions present with a limited duration for survival, only a minority of them survive long enough after Hartmann's procedure to be able to undergo an intervention for stoma closure. It should also be remembered that the emotional disturbances developing in patients with cancer after the first operations may represent another factor contributing to their refusal of the secondstage surgery.

There is no consensus on the timing of the reversal of Hartmann's procedure in the literature. Pearce et al. ${ }^{[16]}$ reported that the most important factor in determining the morbidity and mortality occurring after the reversal of Hartmann's procedure was the accurate timing. They added that it would be appropriate to perform the colostomy closure procedure at the end of the $6^{\text {th }}$ month. In the study performed by Tan et al., ${ }^{[4]}$ the mean duration of the interval between the two stages of operation was found to be 23 weeks. However, it was reported that the timing of the operation was not associated with morbidity or mortality. On the other hand, 17. Geoghegan and Rosenberg[ ${ }^{[17]}$ stated that the rate of complications was lower if the reversal procedure was performed within the first month. In our study, the mean period between the two surgical procedures was 185 days on average and this is an acceptable period of time compared to the literature.

In our study, the average duration of the second stage operations was 185 minutes, which is compatible with the reports in the literature. ${ }^{[4,18]}$ We suggest that the main factor affecting the duration of the second stage operation is the development of adhesions due to the first surgical intervention or due to the radiotherapy given to the malignant cases. The presence of intense adhesions and fibrotic tissues observed in the cases developing complications, especially after the firststage operation, makes the dissection more challenging and leads to the extension of the duration of the operation. 
When we examined the morbidity and mortality rates associated with the reversal of Hartmann's procedure in the literature, we identified that these rates occur in quite a wide range. In a study by Roque-Castellano et al., ${ }^{[6]}$ which included 162 patients, morbidity, and mortality rates were reported to be $54 \%$ and $0.0 \%$, respectively. On the other hand, Zarnescu et al., ${ }^{[7]}$ reported morbidity and mortality rates to be $16 \%-3 \%$, respectively and Tan et al. ${ }^{[4]}$ reported $20.4 \%-0.0 \%$, respectively. In our study, morbidity and mortality rates for the reversal of Hartmann's procedure were $37.5 \%$ and $0.0 \%$, respectively. These rates are found to be at acceptable levels compared with those reported in the literature.

The main factors associated with the high morbidity and mortality rates of the first stage operation were the majority of the patients being older, the presence of accompanying comorbidities (88.5\% of cases were ASA $2-3$ ), the presence of malignant diseases leading to additional nutritional disorders, and patients being in septic shock at the time of admission. Even if the second stage is successful, we must remember that there are risks. We believe that the right patient selection, selection of the appropriate operation time according to the patient, evaluation of the distal segment with preoperative contrast radiography, preoperative preparation of the patient and optimal application of surgical dissection are the main reasons for the mortality rate is $0 \%$ in our patients who underwent the reversal of Hartmann.

In recent years, parallel to the increasing experience of surgeons in laparoscopy, the laparoscopic reversal of Hartmann's procedure has gained its popularity. Many studies have reported that the laparoscopic approach is superior to the open technique concerning the following parameters, including the duration of hospital stay, the presence of intraoperative bleeding, postoperative pain, the return of bowel functions, and the rates of morbidity and mortality. ${ }^{[19-22]}$

Despite the high morbidity and mortality risks associated with the Hartmann's procedure, its significance persists as a damage control surgical technique in the emergencies of the left colon for surgeons and patients. The reversal of Hartmann's procedure appears to be a safe operation with acceptable morbidity rates. If the correct patient selection, correct operation timing and meticulous surgical preparation are performed, the risk of morbidity and mortality of the reversal of Hartmann's procedure can be minimized.

\section{Ethics Committee Approval: Retrospective study.}

Peer-review: Internally peer-reviewed.

Authorship Contributions: Concept: O.A., O.Ş.; Design: O.A., M.Y.; Supervision: O.A., Materials: B.C.T., M.Y.; Data: O.A., B.C.T., S.S.U.; Analysis: O.A., O.Ş.; Literature search: O.A.; Writing: O.A.; Critical revision: O.Ş.

Conflict of Interest: None declared.
Financial Disclosure: The autors declared that this study has received no financial support.

\section{REFERENCES}

1. Hartmann H. Note sur un procede nouveau d'extirpation des cancers de la parti edu colon.[Article in French] Bull Maem Soc Chir Paris 1923;49:1474-77.

2. Desai DC, Brennan EJ Jr, Reilly JF, Smink RD Jr. The utility of the Hartmann procedure. Am J Surg 1998;175:152-4. [CrossRef]

3. Stone HH, Fabian TC. Management of perforating colon trauma: randomization between primary closure and exteriorization. Ann Surg 1979;190:430-6. [CrossRef]

4. Tan WS, Lim JF, Tang CL, Eu KW. Reversal of Hartmann's procedure: experience in an Asian population. Singapore Med J 2012;53:46-51.

5. Schmelzer TM, Mostafa G, Norton HJ, Newcomb WL, Hope WW, Lincourt AE, et al. Reversal of Hartmann's procedure: a high-risk operation? Surgery 2007;142:598-606; discussion 606-7. [CrossRef]

6. Roque-Castellano C, Marchena-Gomez J, Hemmersbach-Miller M, Acosta-Merida A, Rodriguez-Mendez A, Fariña-Castro R, et al. Analysis of the factors related to the decision of restoring intestinal continuity after Hartmann's procedure. Int J Colorectal Dis 2007;22:1091-6. [CrossRef]

7. Zarnescu Vasiliu EC, Zarnescu NO, Costea R, Rahau L, Neagu S. Morbidity after reversal of Hartmann operation: retrospective analysis of 56 patients. J Med Life 2015;8:488-91.

8. Haas PA, Haas GP. A critical evaluation of the Hartmann's procedure. Am Surg 1988;54:380-5.

9. Bakker FC, Hoitsma HF, Den Otter G. The Hartmann procedure. Br J Surg 1982;69:580-2. [CrossRef]

10. Hallam S, Mothe BS, Tirumulaju R. Hartmann's procedure, reversal and rate of stoma-free survival. Ann R Coll Surg Engl 2018;100:301-7. [CrossRef]

11. Oomen JL, Cuesta MA, Engel AF. Reversal of Hartmann's procedure after surgery for complications of diverticular disease of the sigmoid colon is safe and possible in most patients. Dig Surg 2005;22:419-25. [CrossRef]

12. Biondo S, Jaurrieta E, Martí Ragué J, Ramos E, Deiros M, Moreno P, et al. Role of resection and primary anastomosis of the left colon in the presence of peritonitis. Br J Surg 2000;87:1580-4. [CrossRef]

13. Khan AL, Ah-See AK, Crofts TJ, Heys SD, Eremin O. Reversal of Hartmann's colostomy. J R Coll Surg Edinb 1994;39:239-42.

14. Banerjee S, Leather AJ, Rennie JA, Samano N, Gonzalez JG, Papagrigoriadis S. Feasibility and morbidity of reversal of Hartmann's. Colorectal Dis 2005;7:454-9. [CrossRef]

15. Leong QM, Koh DC, Ho CK. Emergency Hartmann's procedure: morbidity, mortality and reversal rates among Asians. Tech Coloproctol 2008;12:21-5. [CrossRef]

16. Pearce NW, Scott SD, Karran SJ. Timing and method of reversal of Hartmann's procedure. Br J Surg 1992;79:839-81. [CrossRef]

17. Geoghegan JG, Rosenberg IL. Experience with early anastomosis after the Hartmann procedure. Ann R Coll Surg Engl 1991;73:80-2.

18. Boland E, Hsu A, Brand MI, Saclarides TJ. Hartmann's colostomy reversal: outcome of patients undergoing surgery with the intention of eliminating fecal diversion. Am Surg 2007;73:664-8.

19. Costantino GN, Mukalian GG. Laparoscopic reversal of Hartmann's procedure. J Laparoendoscopic Surg 1994;4:429-33. [CrossRef]

20. Mazeh H, Greenstein AJ, Swedish K, Nguyen SQ, Lipskar A, Weber KJ, et al. Laparoscopic and open reversal of Hartmann's procedure--a comparative retrospective analysis. Surg Endosc 2009;23:496-502. [CrossRef]

21. Toro A, Ardiri A, Mannino M, Politi A, Di Stefano A, Aftab Z, et 
al. Laparoscopic Reversal of Hartmann's Procedure: State of the Art 20 Years after the First Reported Case. Gastroenterol Res Pract 2014;2014:530140. [CrossRef]
22. Walklett CL, Yeomans NP. A retrospective case note review of laparoscopic versus open reversal of Hartmann's procedure. Ann R Coll Surg Engl 2014;96:539-42. [CrossRef]

\section{ORIJINAL ÇALIŞMA - ÖZET}

\section{Hartmann kapatılması prosedürü hâlâ yüksek morbiditeli bir cerrahi midir?}

\section{Dr. Ozan Akıncı, ${ }^{1}$ Dr. Müge Yurdacan, ${ }^{2}$ Dr. Başar Can Turgut, ${ }^{2}$ Dr. Server Sezgin Uludağ, ${ }^{2}$ Dr. Osman Şimşek ${ }^{2}$}

${ }^{1}$ Hakkari Devlet Hastanesi, Genel Cerrahi Kliniği, Hakkari

2'̇stanbul Üniversitesi-Cerrahpaşa, Cerrahpaşa Tıp Fakültesi, Genel Cerrahi Anabilim Dalı, İstanbul

AMAÇ: Bu çalışma Hartmann prosedürü kapatılmasının ameliyat öncesi ve ameliyat sırasında risk faktörlerine dayanarak sonuçlarını değerlendirmektedir.

GEREÇ VE YÖNTEM: Kliniğimizde Ocak 20।0-Ocak 2016 yılları arasında Hartmann prosedürü uygulanan 78 olgu geriye dönük olarak incelendi. BULGULAR: Olguların 45’i erkek, 33'ü kadındı. OIguların 32'si malignite, I5’i divertikül perforasyonu, II'i sigmoid volvulus nedeniyle ameliyat edilmiştir. Otuz iki olguda Hartmann kapatılması yapılabilmiştir. Hartmann kapatılması için morbidite ve mortalite oranları sırasıyla \%37.5-\%0.0 idi. TARTIŞMA: Hartmann prosedürü kapatılması kabul edilebilir morbidite oranları ile güvenilir bir cerrahi olarak görünmektedir. Doğru hasta seçimi, doğru operasyon zamanlaması ve titiz bir cerrahi hazırlık yapıldığı takdirde Hartmann prosedürü kapatılmasının morbidite ve mortalite riski minimalize edilebilir.

Anahtar sözcükler: Hartmann kapatılması; Hartmann prosedürü, morbidite; mortalite.

Ulus Travma Acil Cerrahi Derg 2020;26(2):255-259 doi: 10.14744/tjtes.2019.7I725 